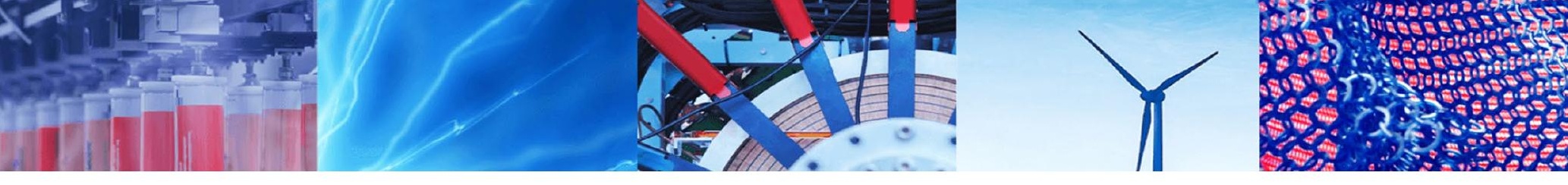

Research Article

\title{
Effect of final temperature on charcoal stiffness and its correlation with wood density and hardness
}

\author{
Raul de Abreu Neto ${ }^{1,2}$ (D) Albert Augusto de Assis $^{3} \cdot$ Adriano Wagner Ballarin $^{3}$ (D) Paulo Ricardo Gherardi Hein ${ }^{1}$ (I)
}

Received: 21 February 2020 / Accepted: 24 April 2020 / Published online: 5 May 2020

(c) Springer Nature Switzerland AG 2020

\begin{abstract}
Mechanical performance is important for charcoal used in blast furnaces as charcoal layers may support the load of iron ore within blast furnaces without breaking. Pyrolysis temperature influences charcoal quality and its chemical composition; however, the effect of temperature on physical-mechanical properties is still unknown. Thus, the aim of this study was to establish the effect of pyrolysis temperature on the density, stiffness and hardness of charcoal and the correlations among them. Four pyrolysis processes were performed at final temperatures of $300,450,600$ and $750{ }^{\circ} \mathrm{C}$ using wood specimens from nine different tree species. Stiffness of wood and charcoal was determined by ultrasound and dynamic hardness by a portable hardness tester. In short, density, dynamic hardness and stiffness of charcoal tend to decrease with increasing temperature. Pyrolysis at $450^{\circ} \mathrm{C}$ decreases charcoal stiffness by approximately $30 \%$, while hardness is reduced from $29 \mathrm{MPa}$ in wood specimens to approximately $3 \mathrm{MPa}$ in charcoal pieces produced from the same specimens. Considering the wood, the highest values of stiffness were presented by the same materials which presented highest density, confirming high positive correlation between wood properties. The correlation between density and stiffness in charcoal is higher than in wood. However, correlation between density and dynamic hardness or stiffness and dynamic hardness is higher for wood than for charcoal. Ultrasound was able to determine differences in stiffness between the materials at different pyrolysis temperatures. These findings are useful to identify the best production temperature for industrial charcoal with adequate mechanical properties.
\end{abstract}

Keywords Carbonization · Rigidity · Specific gravity · Nondestructive testing $\cdot$ Green steel

\section{Introduction}

Pyrolysis process causes physical, anatomical and mechanical changes within the wood that influence the properties of the resulting charcoal and its final quality. As pyrolysis temperature affects cellular composition and degrades wood components, the carbonized material mainly composed of graphitic carbon [1]. Dufourny et al. [2] have stated that quality of charcoal also depends on the characteristics of the precursory wood. Quality control of charcoal is defined by steel industry, which concern is directly related to its behavior in furnace. Mechanic performance of charcoal is one of the most important properties inside the blast furnace, where charcoal layers should support the load of pig ore within blast furnaces without collapsing.

Among the most important biomass traits, wood density [3-5], wood stiffness as indicated by modulus of elasticity in bending or compression $[6,7]$ and wood hardness [8] play a key role in charcoal quality. These combined factors may influence critical physical-mechanical properties of charcoal such as density [9], stiffness [10] and hardness

Raul de Abreu Neto, raulctmabreu@gmail.com | 'Department of Forestry Sciences (DCF), Federal University of Lavras (UFLA), Campus Universitario, Lavras, Minas Gerais 37200-000, Brazil. '2Department of Forestry Engineering, Midwestern Parana State University (Unicentro), Irati, Parana, Brazil. ${ }^{3}$ School of Agriculture, Botucatu (FCA), São Paulo State University (UNESP), José Barbosa Barros Street 1780, Botucatu, São Paulo 18610-307, Brazil. 
[11]. The evaluation of mechanical properties of charcoal is useful to classify material raw and use it rationally.

Correlation between hardness and density in wood is well known $[11,12]$ as well as the high correlation between density and stiffness $[13,14]$. Due to variations during the pyrolysis process, the properties of wood and the resulting charcoal can be different $[5,10]$. To our knowledge, only two studies have evaluated hardness [15] and stiffness [16] of charcoal specimens.

Brazil is the main producer of charcoal in the world. In 2018, it produced 6.4 tons, accounting for $11 \%$ of the world's charcoal production $[17,18]$. As one of the few countries in the world to use charcoal on a large scale in the production of "green steel," the country's domestic consumption is highlighted, which one consumed 4.6 million tons of charcoal in the same year [18].

Veiga et al. [10] have evaluated mechanical strength, such as compression tests parallel to fibers and static bending, of charcoal and pointed out the lack of a methodology for charcoal makes it difficult to standardize the tests. Therefore, new solutions are necessary to evaluate the stiffness and hardness of charcoal, and nondestructive equipments can be effective to close this gap.

In the present study, two equipments already successfully tested for wood evaluations were applied to charcoal specimens: (1) an automated portable hardness tester developed to measure dynamic hardness of viscoelastic materials [19], and (2) ultrasound - an effective tool in the inference of physical and mechanical properties of wood that allows indirectly to estimate elastic constants of materials [14]. The combinations of these two approaches can be useful. The ultrasonic method is efficient for fast estimations of mechanical parameters such as modulus of elasticity and rupture [20] while the portable hardness tester has presented promising results for evaluating dynamic hardness of wood [19] and charcoal [15] specimens.
Few studies have dealt with the correlations between mechanical properties of wood and resulting charcoal quality [10]. The relationship among density, stiffness and hardness of charcoal as a function of final pyrolysis temperature remains still unknown. Therefore, the aim of this study was (1) to better understand the effect of pyrolysis temperature on charcoal stiffness and (2) to establish to what extent the relationships between stiffness with density and hardness of charcoal are influenced by pyrolysis temperature.

\section{Material and method}

\subsection{Wood species}

Wood specimens from nine different tree species were studied: one Corymbia citriodora, six Eucalyptus species and two Eucalyptus hybrids from commercial plantations. To test the tools as potential quality differentiators, it was sought to vary species, ages and densities of wood, as described in Table 1. These wood species represent a large genetic variation, among progeny test and Eucalyptus trees for industrial applications in Brazil. The wood presents potential to be used as charcoal to produce steel (Eucalyptus grandis $\times$ Eucalyptus urophylla hybrids -6 years old) and for pulp and paper production (Eucalyptus urophylla $\times$ Eucalyptus grandis hybrids -6.5 years old). These woods were also investigated in the study by Abreu Neto [15] and Ramalho et al. [21].

Wood specimens with nominal dimensions of $25 \times 25 \times 40 \mathrm{~mm}(\mathrm{R} \times \mathrm{T} \times \mathrm{L})$ were produced, 25 pieces of each material were cut $(9 \times 25)$, totalling 225 specimens (Fig. 1a). Wood specimens were conditioned $\left(20^{\circ} \mathrm{C} \pm 1{ }^{\circ} \mathrm{C}\right.$ and $65 \% \pm 3 \% \mathrm{RU}$ ) until EMC was achieved.
Table 1 Description of the species, ages, origins, wood apparent density and statistical analysis of variance (ANOVA) of the studied trees

\begin{tabular}{llllll}
\hline Code & Wood species & Age (years) & Source & $\begin{array}{l}\text { Apparent density of } \\
\text { wood }\left(\mathrm{kg} \mathrm{m}^{-3}\right)\end{array}$ & SD \\
\hline 1 & E. saligna & 37 & $\mathrm{Pt}$ & $988.64^{\mathrm{a}}$ & 37.23 \\
2 & C. citriodora & 37 & $\mathrm{Pt}$ & $967.76^{\mathrm{ab}}$ & 22.36 \\
3 & E. microcorys & 37 & $\mathrm{Pt}$ & $952.76^{\mathrm{ab}}$ & 74.36 \\
4 & E. deglupta & 37 & $\mathrm{Pt}$ & $950.65^{\mathrm{ab}}$ & 39.58 \\
5 & E. cloesiana & 37 & $\mathrm{Pt}$ & $893.36^{\mathrm{b}}$ & 49.51 \\
6 & E. urophylla $\times$ E. grandis & 6.5 & $\mathrm{Cp}$ & $635.55^{\mathrm{c}}$ & 20.11 \\
7 & E. pilulares & 37 & $\mathrm{Pt}$ & $627.06^{\mathrm{c}}$ & 12.74 \\
8 & E. urophylla $\times$ E. grandis & 6 & $\mathrm{Cp}$ & $595.47^{\mathrm{cd}}$ & 45.09 \\
9 & E. dunnii & 37 & $\mathrm{Pt}$ & $512.05^{\mathrm{d}}$ & 45.16 \\
\hline
\end{tabular}

Pt progeny test, $C p$ commercial planting, $S D$ standard deviation. Means followed by the same lowercase words in columns do not differ by $5 \%$ probability by Tukey test 
Fig. 1 Wood specimens (a), ultrasound testing in charcoal specimens (b), charcoal specimen recently tested by durometer (c) and dynamic hardness testing prototype (d)
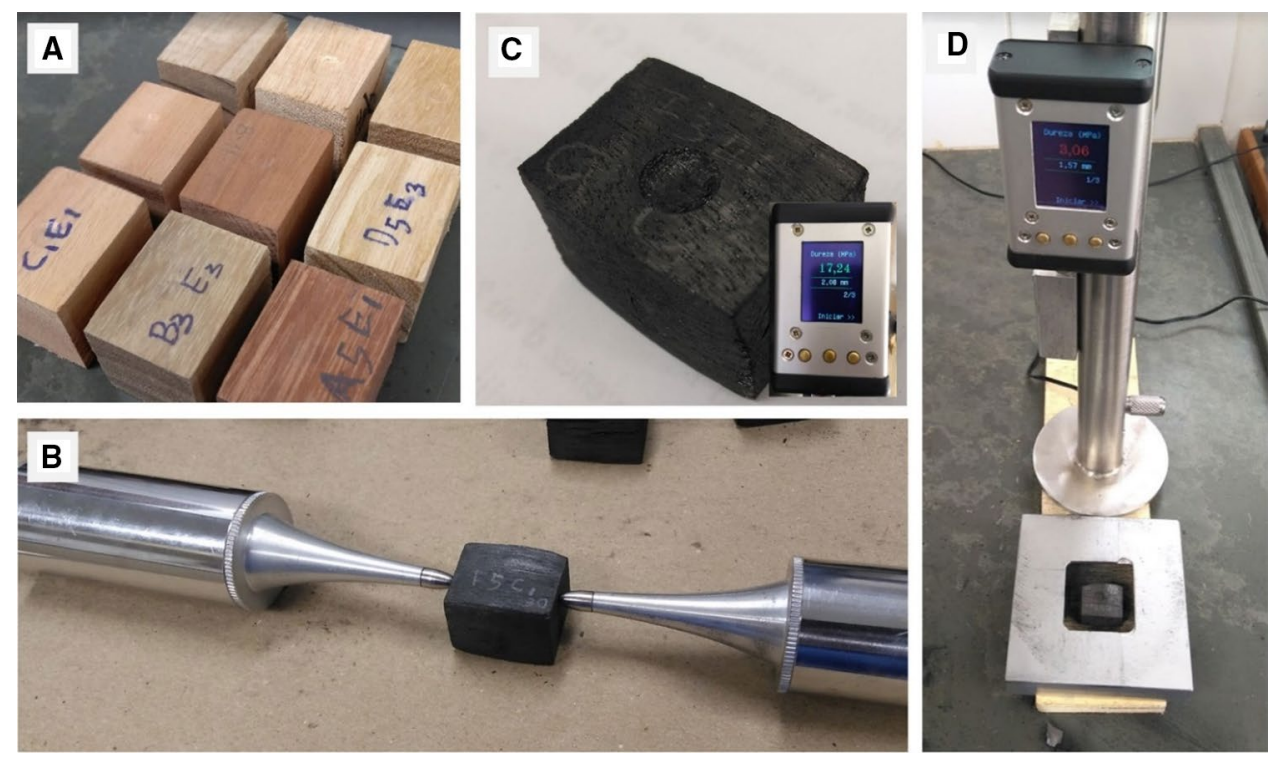

\subsection{Pyrolysis of the material}

To mitigate the propensity to collapse, the wood samples were kiln dried in condition smooth to drastic. Initially, the woods were placed in an oven at 60 degrees until they reached constant mass; after that, they were subjected to treatment at 80 degrees to constant mass and finally, oven set at 100 degrees until reaching constant mass. The samples in dry condition were then subjected to heat treatment at muffle.

Five wood specimens of each species (considered as repetitions) were pyrolyzed inside a carbonization capsule within an electric furnace (muffle) under four thermic treatments, totalling $180(5 \times 9 \times 4)$ charcoal specimens.

Four pyrolysis processes were performed varying final temperatures: $300^{\circ} \mathrm{C}, 450{ }^{\circ} \mathrm{C}, 600^{\circ} \mathrm{C}$ and $750^{\circ} \mathrm{C}$. The initial temperature was $100^{\circ} \mathrm{C}$, the heating rate was $1.67{ }^{\circ} \mathrm{C} \mathrm{min}-1$, and the residence time at final pyrolysis temperature was $30 \mathrm{~min}$, according to the procedure described in the study of Abreu Neto et al. [15], Neves et al. [22] and Protásio et al. [23].

\subsection{Material characterization}

\subsubsection{Charcoal and wood density}

Apparent density of wood was performed by stereometric method, based on Travisan et al. [24] and NBR 14,984 [25]. Specimens were weighed on a $0.01 \mathrm{~g}$ analytical balance and measured with digital caliper to obtain mass and volume, respectively.

The apparent relative density of each charcoal specimen was determined according to hydrostatic method, by determining the volume in water and dry weight of the charcoal.

Twenty-seven specimens of wood were performed, with three replicates for each of nine species analyzed. In addition, one hundred and eight samples of charcoal, with three specimens of each of nine species, which were produced under four different temperatures, were measured.

\subsubsection{Dynamic hardness}

Dynamic hardness (DH) of wood and charcoal was evaluated according to procedure described by Assis et al. [17] and Abreu Neto et al. [15], which used portable hardness tester-DPM3 (Fig. 1d). This device, developed by Brazilian research group, is an electromechanical instrument whose operating principle is similar to the Brinell hardness test [19].

\subsubsection{Stiffness by ultrasound}

Wood and charcoal stiffness was determined by a Steinkamp brand ultrasound device, model BP-7. Device has two equivalent flat piezoelectric transducers-one for emission and another for reception of ultrasound waves, frequency $45 \mathrm{kHz}$ (Fig. 1b). Stiffness (GPa) in longitudinal direction was determined from ultrasound wave propagation speed (dry contact; without gel), as performed by Ballarin et al. [14]. The equipment determines time that the ultrasonic wave takes to cross the material in longitudinal direction. Speed is calculated by the ratio of distance traveled by wave from one end of sample to the other by time (indicated by equipment). Finally, stiffness estimate was obtained using Eq. (1): 
$S=v^{2} \times d$

where: $S$ is stiffness, $v$ is speed of propagation of ultrasound and $d$ is density of wood or charcoal.

A total of 45 measurements were performed on wood specimens, with five replicates for each of nine wood species analyzed. In addition, five specimens of each species, which were produced under four different temperatures, were measured for charcoal, totalling 180 charcoal specimens. Thus, a total of 225 specimens of wood $(n=45)$ and charcoal $(n=180)$ were analyzed.

Collapses and cracks easily and frequently arise during the wood-to-charcoal conversion process. After pyrolysis process, these specimens were visually verified and apparently were free from collapse, but this was not actually measured. The charcoal specimens showed only small cracks that we consider negligible for the purpose of this study.

\subsubsection{Statistical analysis of the data}

Analysis of variance (ANOVA), Tukey's test and regressions were performed to analyze differences between species and temperatures in the variables stiffness, hardness and density. The level of significance was $5 \%$.

\section{Results and discussion}

\subsection{Wood stiffness by ultrasound}

Figure 2 shows the variation of wood stiffness and density according to the wood. The mean wood stiffness was
$3.920 \mathrm{GPa}$, and mean wood density was $0.791 \mathrm{~g} \mathrm{~cm}^{-3}$. The highest values of wood stiffness were presented by C. citriodora (Code 2), E. deglupta (Code 4) and E. microcorys (Code 3 ). The same materials also presented highest densities, suggesting high positive correlation between these wood properties, as expected. E. saligna (Code 1) presented the largest specific modulus (ratio between stiffness and density), indicating the most light and resistant material.

Many studies have shown that ultrasound technique is able to estimate wood stiffness $[13,14,20]$. However, the application of this equipment in brittle materials such as charcoal is scarce. If wood-to-charcoal correlations exist, estimating wood stiffness can be useful for identification of potential materials for use as charcoal.

Almeida et al. [13] studied Dinizia excelsa Ducke and reported wood stiffness of approximately 23,919 MPa. The authors found a low correlation with modulus of elasticity and static bending and attributed this result to differences in moisture conditions. Stangerlin et al. [20] used an ultrasound device to evaluate Peltophorum dubium (Spreng.) Taub. wood and found elastic constants close to $7800 \mathrm{MPa}$. The authors mention morphological and anatomical properties may have influenced results. The authors observed dynamic constant is 1.3 times greater than modulus of elasticity due to the viscoelastic behavior of wood. Ballarin et al. [14] performed ultrasonic stiffness measurements to evaluate juvenile wood and adult wood of Pinus taeda L. and found values of 11,816 and $17,914 \mathrm{MPa}$, respectively. Wood stiffness values founded in the literature are greater than observed in this study. Specimens size used in this study
Fig. 2 Wood stiffness (GPa) by wood species in longitudinal direction (bar) and apparent density $\left(\mathrm{kg} \mathrm{m}^{-3}\right)$ (line). Means followed by the same lowercase letters in a column and capital letters on the lines did not differ significantly by Tukey test at $5 \%$ significance

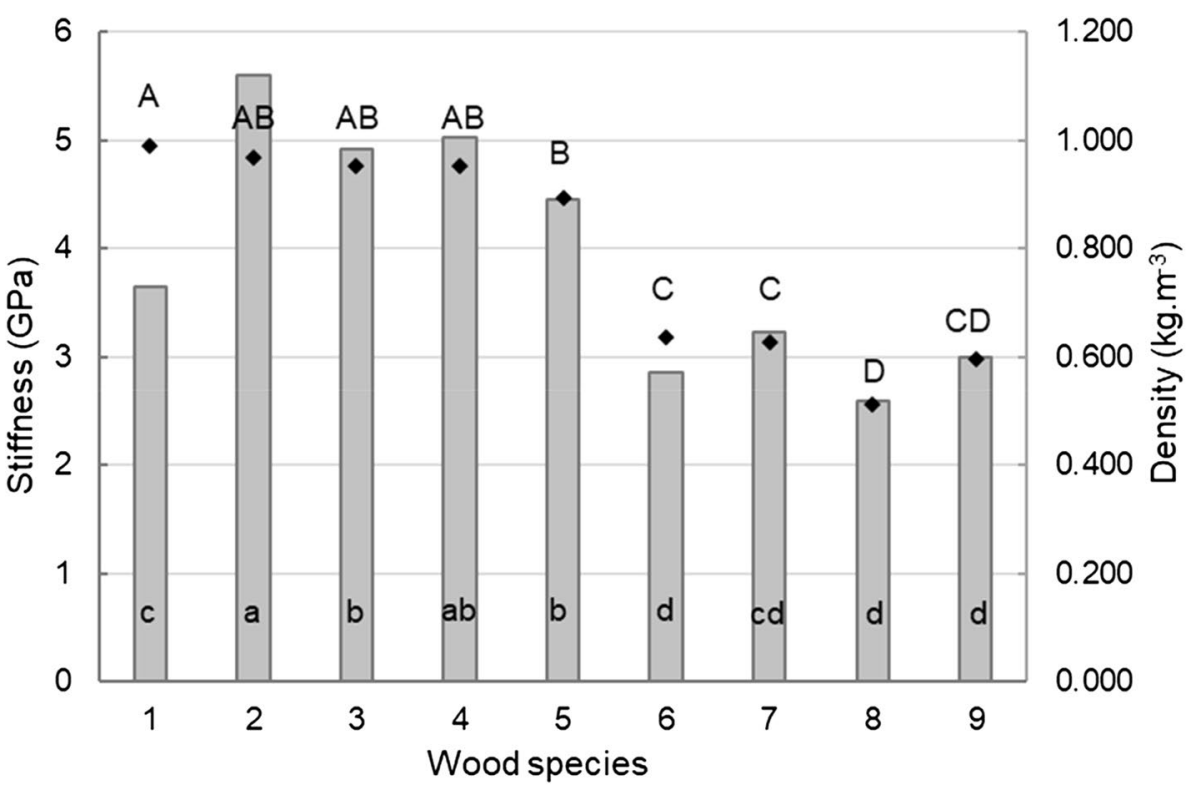


may have influenced this result, since ultrasonic stiffness is measured as a function of distance travelled by wave.

\subsection{Stiffness of wood species as a function of final pyrolysis temperature}

Figure 3 shows charcoal stiffness and density results of different species at temperatures of $300,450,600$ and $750^{\circ} \mathrm{C}$. In general, the E. saligna (Code 1), C. citriodora (Code 2) and E. microcorys (Code 3) had the highest stiffness values; concomitantly, these materials presented highest values of density, regardless of thermal treatment used (Fig. 3). Interestingly, wood and charcoal of materials 2 and 3 presented highest stiffness and density values while wood and charcoal of material 9 presented lowest stiffness and density values. It is important to note that wood and charcoal were considered as an anisotropic material.

Ultrasound was able to estimate stiffness of materials even after thermal treatment. The equipment was also able to determine differences in stiffness between studied materials at different pyrolysis temperatures. These findings are useful to identify the best production temperature of charcoal based on mechanical properties.
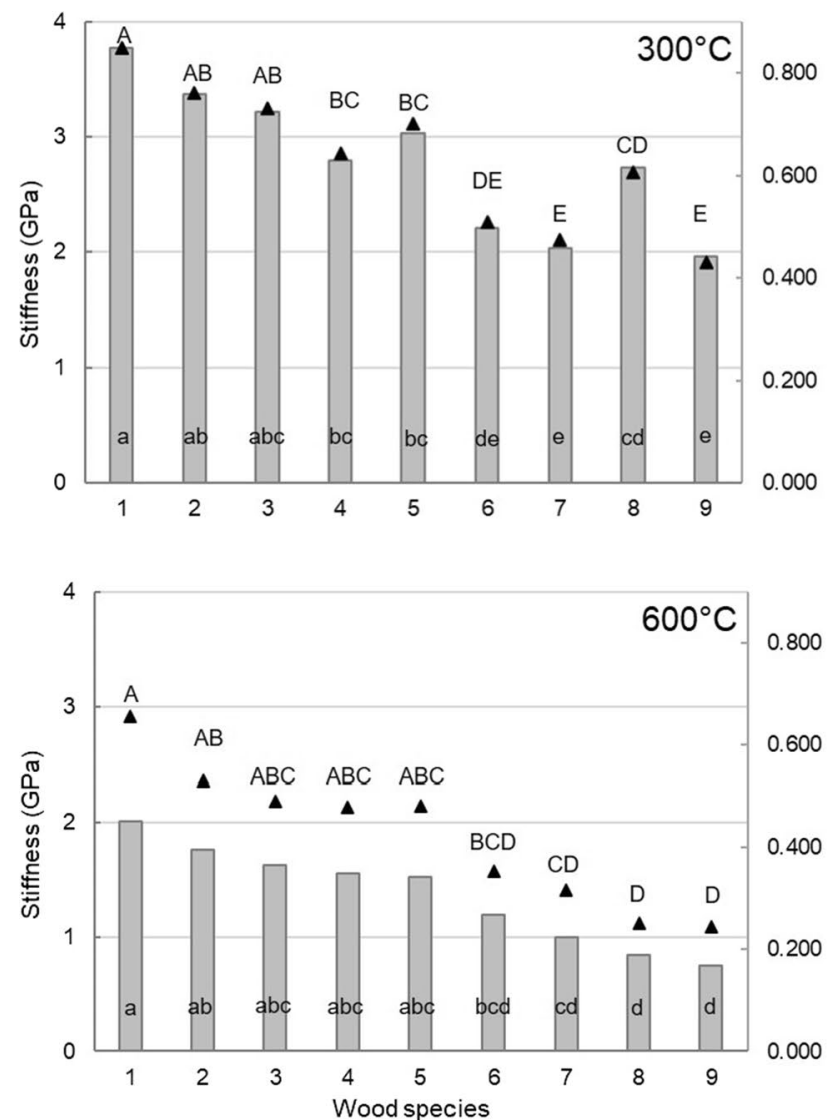

Veiga et al. [10] have observed that C. citriodora presented higher stiffness, $1.585 \mathrm{MPa}$, compared to $E$. urophylla, around $900 \mathrm{MPa}$. Citriodora specimens are also more resistant ( $5 \mathrm{MPa}$ ) than Eucalyptus urophylla (3 $\mathrm{MPa})$. Poncsák et al. [26] have investigated birch wood (Betula papyrifera) with $\mathrm{MOE}$ around $1.500 \mathrm{MPa}$. According to them, after thermal treatment around $120^{\circ} \mathrm{C}$ the value decreases to nearly $1.200 \mathrm{MPa}$. The authors have reported a maximum peak in the MOE value at $160^{\circ} \mathrm{C}$, and MOE decreases with increasing temperature. It was also mentioned that exothermic chemical reactions start between 150 and $160^{\circ} \mathrm{C}$, probably due to the decomposition of hemicelluloses and cellulose polymers. This behaviour appears to be almost constant under experimental conditions below $250^{\circ} \mathrm{C}$.

The findings reported in this study are close to those observed in the literature $[10,26]$. Here, the ultrasound technique allows to quickly and nondestructively observe the tendency to decrease stiffness.
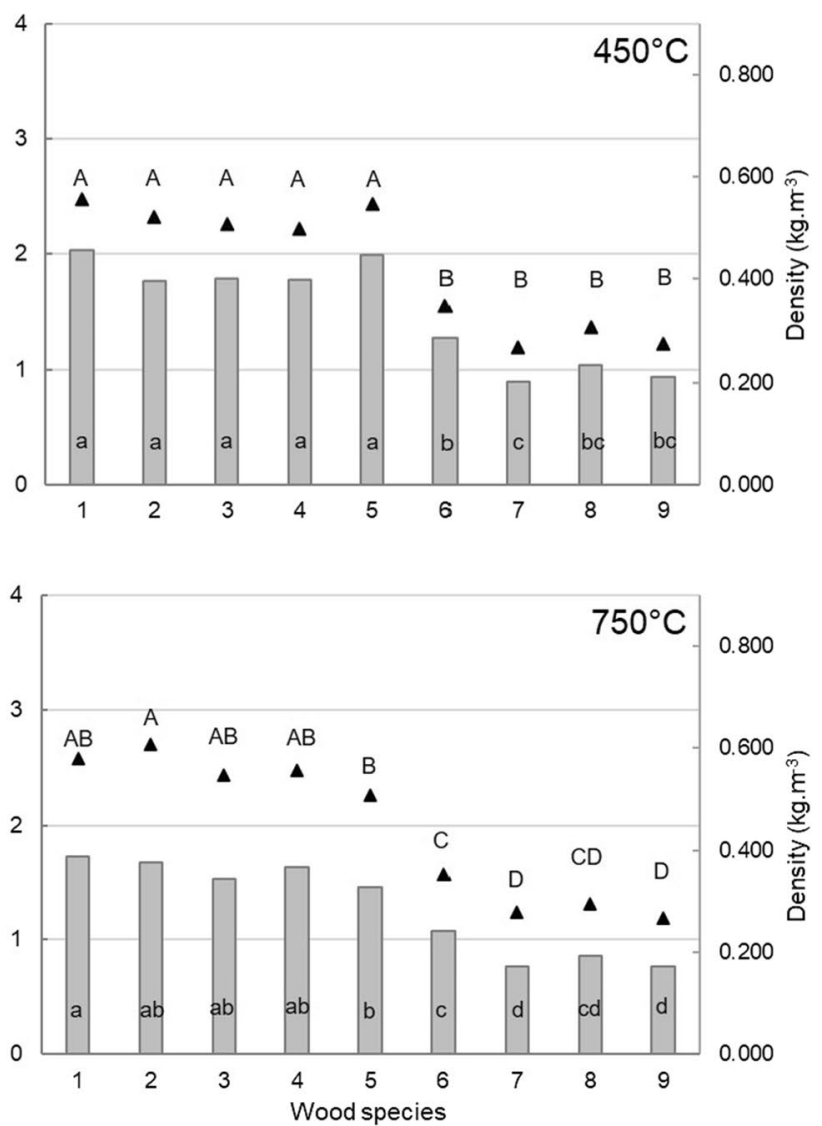

Fig. 3 Charcoal stiffness and density of materials produced at final temperatures of $300,450,600$ and $750{ }^{\circ} \mathrm{C}$. Means followed by the same lowercase letters in a column and capital letters on the lines did not differ significantly by Tukey test at $5 \%$ significance 
Table 2 Apparent density, stiffness in longitudinal direction and dynamic hardness of wood and charcoal of nine species at different final pyrolysis temperatures

\begin{tabular}{llll}
\hline $\begin{array}{l}\text { Final tem- } \\
\text { perature }\left({ }^{\circ} \mathrm{C}\right)\end{array}$ & Density $\left(\mathrm{kg} \mathrm{m}^{-3}\right)$ & $\begin{array}{l}\text { Dynamic hard- } \\
\text { ness (MPa) }\end{array}$ & Stiffness (GPa) \\
\hline Control & $791.48^{\mathrm{a}}$ & $29.82^{\mathrm{a}}$ & $3920^{\mathrm{a}}$ \\
300 & $634.88^{\mathrm{b}}$ & $10.72^{\mathrm{b}}$ & $2794^{\mathrm{b}}$ \\
450 & $424.86^{\mathrm{c}}$ & $3.25^{\mathrm{c}}$ & $1496^{\mathrm{c}}$ \\
600 & $422.85^{\mathrm{c}}$ & $3.59^{\mathrm{c}}$ & $1362^{\mathrm{c}}$ \\
750 & $444.15^{\mathrm{c}}$ & $4.63^{\mathrm{c}}$ & $1278^{\mathrm{c}}$ \\
\hline
\end{tabular}

Averages followed by the same lowercase letter in column are not considered statistically different using the Scott Knott test, at significance of $5 \%$

\subsection{Physical-mechanical properties of charcoal as a function of final pyrolysis temperature}

Physical and mechanical properties of materials decreased with temperature (Fig. 3). Compared to wood, density of material converted to charcoal produced at 450, 600 and $750{ }^{\circ} \mathrm{C}$ presented lower and statistically equal density values (Table 2). According to Veiga et al. [10], charcoal quality and charcoal stiffness are controlled by the final temperature of carbonization. Here, the results showed that pyrolysis temperature also decreases material hardness.

Wood dynamic hardness presented higher value, approximately $29 \mathrm{MPa}$, compared to charcoal (Table 2). The analysis of variance indicates a significant effect of temperature and material on hardness, with interaction between factors. Dynamic hardness tends to decrease with increasing temperature. For instance, the temperature of $300{ }^{\circ} \mathrm{C}$ decreases dynamic hardness to approximately $10 \mathrm{MPa}, 1 / 3$ of wood hardness. Above $450{ }^{\circ} \mathrm{C}$, the hardness is statistically equivalent, with values close to 3.5 and 4.6 MPa for 600 and $750{ }^{\circ} \mathrm{C}$, respectively. Stiffness of material produced at $300^{\circ} \mathrm{C}$ is $2794 \mathrm{MPa}, 28 \%$ lower compared to wood ( $3920 \mathrm{MPa}$ ) as shown in Table 2. Charcoal presented lower stiffness with increasing production temperature. Charcoal specimens produced at 450,600 and $750{ }^{\circ} \mathrm{C}$ showed lower values of stiffness, and statistically equal to each other.

In addition to decreasing mechanical properties, temperature also decreases material heterogeneity (Fig. 4).

The heat treatment decreases the stiffness variation of material; control treatment presents amplitude of variation around $3013 \mathrm{MPa}$. The final pyrolysis temperature of $300{ }^{\circ} \mathrm{C}$ produced material with a range of variation of approximately $1334 \mathrm{MPa}$. At temperature of $750^{\circ} \mathrm{C}$, variation is $963 \mathrm{MPa}$. Compared with wood variation, pyrolysis temperature of $750^{\circ} \mathrm{C}$ produces charcoal with variation approximately 3 times lower.

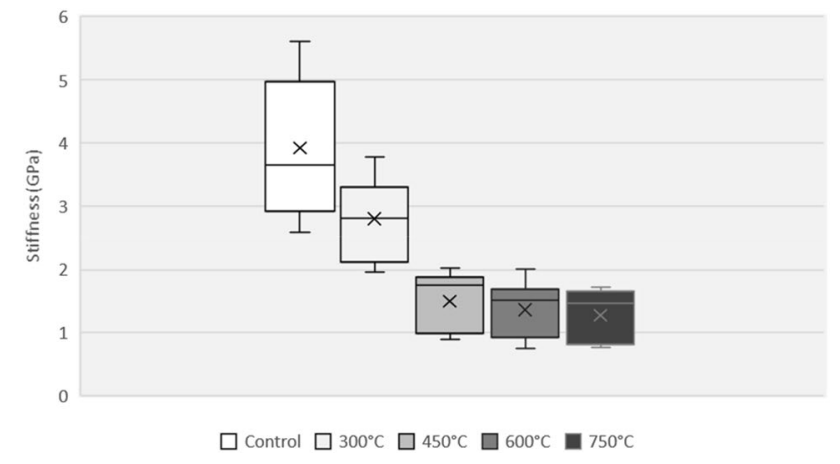

Fig. 4 Variation of charcoal stiffness as a function of final pyrolysis temperature

Veiga et al. [10] have studied C. citriodora and E. urophylla also observed higher stiffness of wood, an average of $7552 \mathrm{MPa}$, compared to charcoal produced at $450^{\circ} \mathrm{C}$, average of $1115 \mathrm{MPa}$. The authors performed mechanical tests in a universal test machine, in accordance with BS-373 [27] for wood, and adapted the methodology for analysis of charcoal stiffness.

Coutinho et al. [28] have reported a reduction in density, from 310 to $180 \mathrm{~kg} \cdot \mathrm{m}^{-3}$, with an increasing temperature from 400 to $1000{ }^{\circ} \mathrm{C}$. Trugilho et al. [9] observed decrease in apparent relative density with an increase in pyrolysis temperature $\left(300\right.$ to $700^{\circ} \mathrm{C}$ ). The authors concluded there is a minimum density point in carbonized materials at $660^{\circ} \mathrm{C}$; above this temperature, for instance $900^{\circ} \mathrm{C}$, density increases.

Poncsák et al. [26] have investigated mechanical properties of birch and observed that there is a maximum hardness at about $160{ }^{\circ} \mathrm{C}$, values close to 22 and $28 \mathrm{MPa}$ for samples analyzed radially and transversely, respectively. The authors observed birch hardness reduction with an increase in holding time at the maximum temperature $220^{\circ} \mathrm{C}$, due to a greater structural degradation. Values found are very close to those found in this study. According to Veiga et al. [29], the reduction in mechanical traits observed can be explained by the formation of cracks during carbonization process.

In short, the ultrasound technique was effective for identifying stiffness of charcoal. The results showed that the ultrasound equipment was sensitive to variations in mechanical properties of different wood species at all pyrolysis temperatures analyzed. Abreu Neto et al. [15] presented results on charcoal hardness suggesting that this hardness tester equipment can be used as a reference for mechanical classification of charcoal in steel industries. 
Fig. 5 Correlations among physical-mechanical properties of wood (control) and charcoal produced at different final temperatures

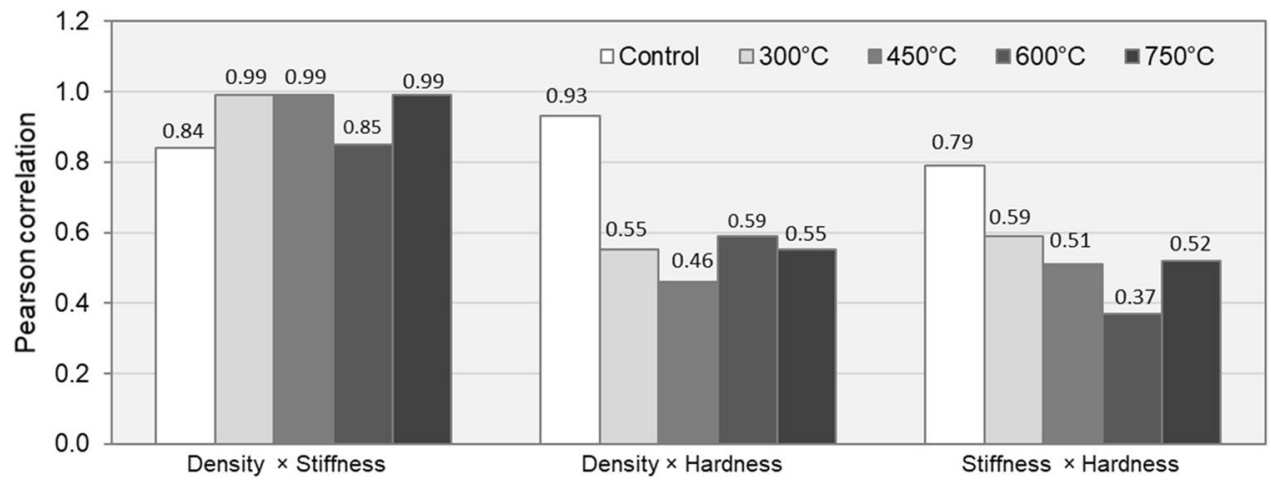

\subsection{Correlations among physical-mechanical properties of wood and charcoal}

Correlation among physical-mechanical properties of charcoal is higher than found in wood, regardless of final pyrolysis temperature. There was high correlation between wood density and stiffness, $r=0.84$ (Fig. 5); this correlation increases to $r=0.95$ with application of heat treatment (Fig. 6a). These results were consistent with those found in the literature [30,31].

It is possible to observe correlation of $r=0.93$ between density and dynamic hardness (DH) of wood (Fig. 5). Final pyrolysis temperature negatively affects the correlation between these properties; correlation decreases to $r=0.53$ (Fig. 6b). Correlation between stiffness and dynamic hardness of wood was $r=0.79$ (Fig. 5). Correlation of thermally treated material is lower compared to Control material, around $r=0.50$ (Fig. 6c).

It is known mechanical properties of wood correlate well with density [30]. For charcoal, Couto et al. [32] observed a higher relative apparent density and greater stiffness. The authors observed rearrangement and greater organization of carbon chains under higher final carbonization temperature, producing charcoal with higher stiffness. Veiga et al. [10] found a high correlation between basic wood density and stiffness $(r=0.732)$. In addition to these results, same authors observed a high correlation between wood strength and wood stiffness $(r=0.898)$ but found a lower correlation for strength and stiffness of charcoal $(r=0.607)$.

A high correlation between hardness and density is in agreement with findings of Antal et al. [31] and Chrzazvez et al. [33], who evaluated relationship between density and mechanical strength. According to data found in the literature, there are positive correlation between basic wood density, modulus of elasticity, gravimetric yield and density of charcoal $[34,35]$.

\section{Concluding remarks}

Heat treatment decreases the stiffness of wood. Pyrolysis at $450{ }^{\circ} \mathrm{C}$ reduced charcoal stiffness by approximately $30 \%$ compared to wood. Considering the wood species, the highest values of stiffness were presented by C. citriodora and E. deglupta, same materials presented highest density, confirming high positive correlation between wood properties.

Correlation between density and stiffness is higher for charcoal ( $r=0.95$, in average) than for wood ( $r=0.84$ ). However, correlation between density and dynamic hardness or stiffness and dynamic hardness is higher for wood than for charcoal. Correlation between density and dynamic hardness was 0.93 for wood specimens and 0.53 , in average, for charcoal specimens. Correlation between stiffness and dynamic hardness was 0.79 for wood and 0.50 , in average, when the materials are converted to charcoal. 

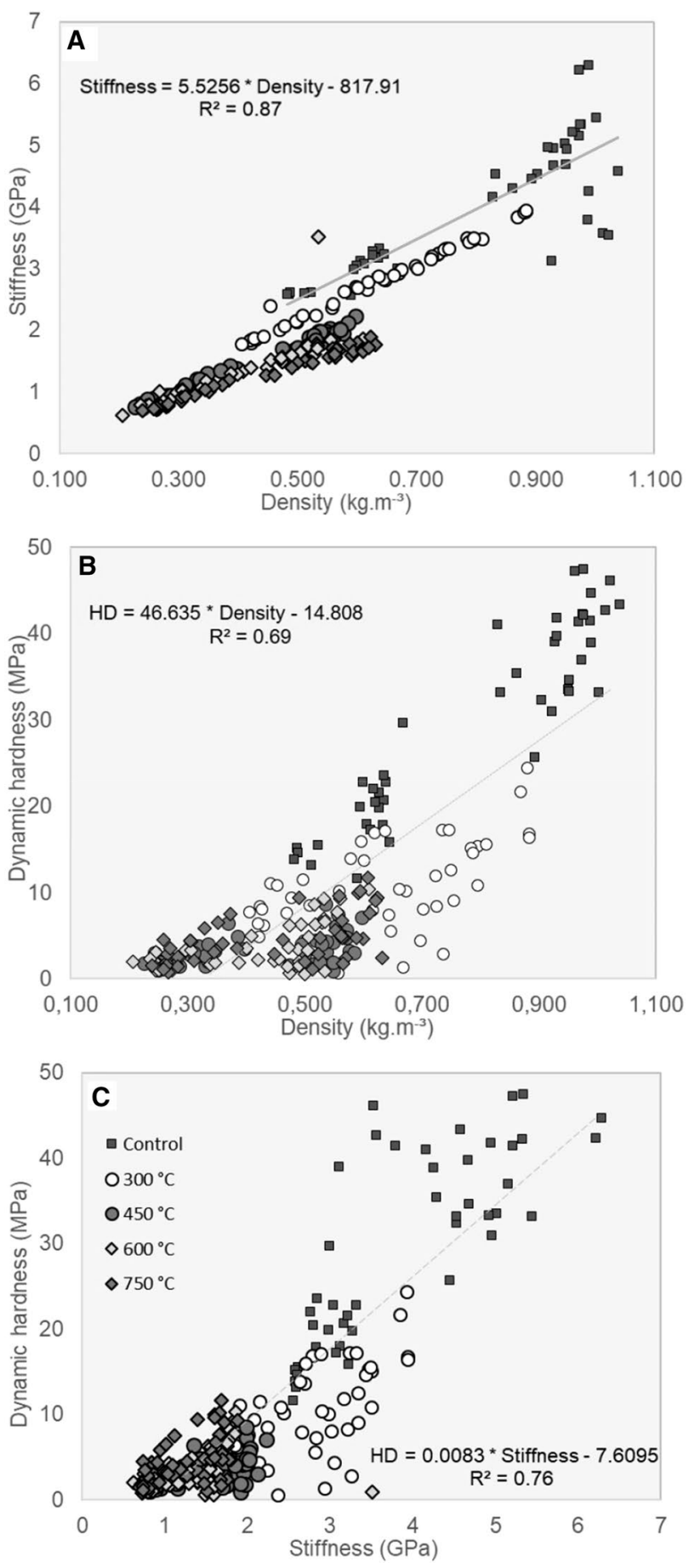

Fig. 6 Correlations between apparent relative a density $\times$ stiffness, b density $\times \mathrm{HD}$ (dynamic hardness) and $\mathbf{c}$ stiffness $\times$ dynamic hardness for all final pyrolysis temperatures

Acknowledgements The authors express special thanks to the Wood Science and Technology Laboratory of the Federal University of Lavras (UFLA, Brazil) and School of Agriculture - campus Botucatu (FCA) of São Paulo State University (UNESP) for supporting the experimental work. This study was funded by National Council for Scientific and Technological Development (CNPq Brazil, Grant No. 405085/2016-8), Higher Education Personnel Improvement Coordination (CAPES, Brazil) and Foundation for Research Support of the State of Minas Gerais (FAPEMIG Brazil, Grant No. APQ-00509-14). PRG Hein was supported by CNPq (Grant No. 303675/2017-9) grants.

Availability of data and material The material and database are available.

\section{Compliance with ethical standards}

Conflict of interest The authors declare that they have no conflict of interest.

\section{References}

1. Xu D, Ding T, Li Y, Zhang Y, Zhou D, Wang S (2017) Transition characteristics of a carbonized wood cell wall investigated by scanning thermal microscopy (SThM). Wood Sci Technol 51:831-843

2. Dufourny A, Van De Steene L, Humbert G, Guibal D, Martin L, Blin J (2018) Influence of pyrolysis conditions and the nature of the wood on the quality of charcoal as a reducing agent. J Anal Appl Pyrol 137:1-13. https://doi.org/10.1016/j. jaap.2018.10.013

3. Loureiro BA et al (2019) Selection of superior clones of Corymbia hybrids based on wood and charcoal properties. Maderas Cienc Tecnol 21(4):619-630. https://doi.org/10.4067/S0718-221X2 019005000417

4. Ramos DC, Carneiro ADCO, Tangstad M, Saadieh R, Pereira BLC (2019) Quality of Wood and Charcoal from Eucalyptus Clones for Metallurgical Use. Floresta Ambiente. https://doi. org/10.1590/2179-8087.043518

5. Nones DL, Brand MA, Cunha AB, Carvalho AF, Weise SMK (2015) Determination of energy properties of wood and charcoal produced from Eucalyptus benthamii. Floresta 45:57-64. https://doi. org/10.5380/rf.v45i1.30157

6. Babich A, Senk D, Fernandez M (2010) Charcoal behavior by its injection into the modern blast furnace. ISIJ Int 50:81-88

7. Castro AFNM, Castro RVO, Carneiro ACO, Santos RC, Carvalho AMML, Trugilho PF, Melo ICNA (2016) Correlations between age, wood quality and charcoal quality of Eucalyptus clones. Rev Árvore 40:551-560

8. Hirata S, Ohta M, Honma Y (2001) Hardness distribution on wood surface. J Wood Sci 47:1-7

9. Trugilho PF, Silva DA (2001) Influence of final carbonization temperature on physical and chemical characteristics of charcoal of Jatobá (Himenea courbaril L). Sci Agrar 2:45-53

10. Veiga TRLA, Lima JT, Monteiro TC, Dessimoni ALA, Rocha MFV (2018) Mechanical properties of individual samples of wood and charcoal of Eucalyptus urophylla and Corymbia citriodora. Sci For 46:107-114

11. Zickler GA, Schöberl T, Paris O (2006) Mechanical properties of pyrolysed wood: a nanoindentation study. J Philos Mag. https ://doi.org/10.1080/14786430500431390

12. Peng H, Jiang J, Zhan T, Lu J (2016) Influence of density and equilibrium moisture content on the hardness anisotropy of wood. For Prod J 7-8(66):443-452. https://doi.org/10.13073/ FPJ-D-15-00072

13. Almeida CFAM, Menezzi CHS, Silva TC (2012) Use of non-destructive evaluation in red beams of Angelim (Dinizia excelsa Ducke). Ciênc Madeira (Braz J Wood Sci) 03:128-143 
14. Ballarin AW, Nogueira M (2005) Elasticity modulus determination of juvenile and adult Pinus taeda wood by ultrasound. Eng Agríc 25:19-28

15. Abreu Neto R, Assis AA, Ballarin AW, Hein PRG (2018) Dynamic hardness of charcoal varies according to the final temperature of carbonization. Energy Fuels 32:9659-9665

16. Assis MR, Brancheriau L, Napoli A, Trugilho PF (2016) Factors affecting the mechanics of carbonized wood: literature review. Wood Sci Technol 50:519-536

17. Food and Agriculture Organization of United Nations. FAOSTAT (2019) Roma: FAO [cited 2019 Mar 26]. https://www.fao.org/ faostat/en/\#data

18. IBA - Industria Brasileira de Árvores (Brazilian Tree Industry) Charcoal (2019). Report 2019 [cited 2019 Mar 26]. https://iba. org/datafiles/publicacoes/relatorios/iba-relatorioanual2019.pdf

19. Assis AA, Alexandre RP, Ballarin AW (2017) Dynamic hardness of wood-measurements with an automated portable hardness tester. Holzforschung 71:5. https://doi.org/10.1515/ hf-2016-0137

20. Stangerlin DM, Gatto DA, Melo RR, Calegari L, Vivian MA, Castelo PAR, Beltrame R (2010) Ultrasound to estimate mechanical properties of Peltophorum dubium wood. Ciênc Madeira 1:44-53

21. Ramalho FMG, Hein PRG, Andrade JM, Napoli A (2017) Potential of near-infrared spectroscopy for distinguishing charcoal produced from planted and native wood for energy purpose. Energy Fuels 31:1593-1599

22. Neves TA, Protásio TP, Couto AM, Trugilho PF, Silva VO, Vieira CMM (2011) Avaliação de clones de Eucalyptus em diferentes locais visando à produção de carvão vegetal. Pesqui Florest Bras 31(68):319-330

23. Protásio TP, Guimarães Junior M, Mirmehdi S, Trugilho PF, Napoli A, Knovack KM (2017) Combustion of biomass and charcoal made from babassu nutshell. Cerne 23(1):1-10

24. Trevisan H, Tieppo FMM, Carvalho AG, Lelis RCC (2007) Avaliação de propriedades físicas e mecânicas da madeira de cinco espécies florestais em função da deterioração em dois ambientes. Rev Árvore 31(1):93-101. https://doi.org/10.1590/S0100-67622 007000100011

25. Associação Brasileira de Normas Técnicas. NBR 14984 (2003) Madeira -Determinação da Densidade Aparente de Cavacos. ABNT, Rio de Janeiro
26. Poncsak S, Kocaefe D, Bouazara M, Pichette A (2006) Effect of high temperature treatment on the mechanical properties of birch (Betula papyrifera). Wood Sci Technol 40:647-663

27. BS - British Standards Institution BS 373 (1957) Methods of testing small clear specimens of timber. London, $31 \mathrm{p}$

28. Coutinho AR, Ferraz ESB (1988) Determinação da friabilidade do carvão vegetal em função do diâmetro das árvores e temperatura de carbonização. IPEF 38:33-37

29. Veiga TRLA, Lima JT, Monteiro TC, Rocha MFV, Jesus MS, Goulart SL (2016) Effect of specimen length on mechanical properties of Eucalyptus charcoal. Pesqui Florest Bras 36:399-406

30. Andrade FWC, Tomazello Filho M, Moutinho VHP (2018) Influence of Wood Physical Properties on Charcoal from Eucalyptus spp. Floresta e Ambiente 25:3. https://doi.org/10.1590/21798087.017615

31. Antal MJ, Mok WSL (1990) Review of methods for improving the yield of charcoal from biomass. Energy Fuel 4(3):221-225

32. Couto AM, Trugilho PF, Napoli A, Lima JT, Silva JRM, Protásio TP (2015) Quality of charcoal from Corymbia and Eucalyptus produced at different final carbonization temperatures. Sci For 43:817-831

33. Chrzazvez J, Théry-Parisot I, Fiorucci G, Terral JF, Thibaut B (2014) Impact of post-depositional processes on charcoal fragmentation and archaeobotanical implications: experimental approach combining charcoal analysis and biomechanics. J Archaeol Sci 44:30-42

34. Soares VC, Bianchi ML, Trugilho PF, Pereira AJ, Höfler J (2014) Correlações entre as propriedades da madeira e do carvão vegetal de híbridos de eucalipto. Rev Árvore 38(3):543-549. https ://doi.org/10.1590/S0100-67622014000300017

35. Moutinho VHP, Tomazello Filho M, Brito JO, Ballarin AW, Andrade FWC, Cardoso CC (2017) Characterization and statistical correlation between charcoal's physical and mechanical properties of Eucalyptus and Corymbia clones. Ciênc Florest 27:1095-1103

Publisher's Note Springer Nature remains neutral with regard to jurisdictional claims in published maps and institutional affiliations. 